\title{
THE TECHNOLOGY OF THE FORMATION OF THE FUTURE TEACHERS' READINESS TO THE PREVENTION OF THE PROFESSIONAL SYNDROMES AND ILLNESSES
}

\section{Yuliia Hlinchuk $^{1}$}

DOI: https://doi.org/10.30525/978-9934-588-15-0-5

Abstract. The critical condition of the teachers' health is an important modern issue in pedagogical, humanitarian, medical and social fields. Together with other unfavorable conditions, it influences the health of the rising generation and the effectiveness of the educational process. It is connected with insufficient professional preparation of students of pedagogical specialties in the system of the higher pedagogical education. The subject of the study is the willingness of future teachers to prevent occupational syndromes and diseases. The aim of the research. The goal of the study is to justify theoretically and develop and check experimentally the technology of the formation of the future teachers' readiness to prevent the professional illnesses. When one talks about readiness, one means the state of an individual that allows him/her to enter successfully the professional sphere, and develop quickly in the career [23]. Objectives. The main objectives of the research are to conduct theoretical and methodological analysis and comparison of the scientific research data connected with the aspects of the future teachers' preparation to the health preservation and professional longevity, to develop and check experimentally the technology of the formation of the future educators' readiness to prevent the professional illnesses. Research methods. The main research methods are monitoring and analysis of scientific and methodological literature, comparison and generalization of the results, instructional design, pedagogical experiment, questionnaire, analysis of the respondents' performance, quantity and quality analysis of experimental data. The study was conducted on the basis of the Rivne State University of Humanities. The experiment involved anonymous participation of 120 pedagogical students by voluntary agreement. The following

\footnotetext{
${ }^{1}$ Candidate of Pedagogical Sciences, Lecturer at Departament of General Technical Subjects, Technologies and Public Safety, Rivne State University of Humanities, Ukraine
}

(C) Yuliia Hlinchuk 
article presents the technology of the formation of the future teachers' readiness to the prevention of the professional syndromes and illnesses and the results of its experimental testing. The technology was designed on the basis of the comparison of the data received from the scientific-research literature on the educators' professional illnesses, experimental data concerning the study of the unfavorable factors of the educational environment (including the personal experience of working at school) that influence teachers' health, and analysis of the scientific-methodological works about the preparation of the future teachers to health preservation and professional longevity. The distinguishing feature of the given research is its health and safety nature based on the consideration of the factors that form the working conditions that helps to react flexibly to the ever changing circumstances of the professional activities. Experimental testing of this technology has confirmed its effectiveness. The described technology and its elements can be used in the system of higher or post-graduate pedagogical studies.

\section{Introduction}

The transformation of the school educational system is always connected with the processes that take part in the society. However, at the same time, the school system of education can serve as a powerful factor of social changes influencing the younger generation someway or other. Since a teacher is the key figure of the educational process at school, his personality has direct influence on the success of the educational activity and students' development. What is more, not only the knowledge of the subject or methodological competency play a vital role but also his physical and psychological state. As H. Nikiforov claims, teacher's professional health has impact on the students' health on all levels: emotional, psychological, bioenergetic, informational and disciplinary [16].

His opinion correlates with the conclusions of $\mathrm{H}$. Meshko who has stated that unhealthy teacher cannot pay enough attention to the pupil, guarantee the individual approach, create a situation of success. Moreover, they cannot instill in children the health culture as this requires personal example [13].

M. Mokaieva believes that educators' professional disorders bear transformational character as they directly influence the health of pupils and parents [15]. 
Unfortunately, currently, Ukrainian educators as well as those from many other countries are a category of workers whose level of professional illnesses is critical.

Thus, O. Kolomiitseva has discovered that $62.3 \%$ of teachers suffer from overload of regulatory systems and adaptation failures, and $21 \%$ have nerve illnesses [10].

According to the results of the research by B. Dolinskii, $78 \%$ of school teachers continually feel the psychological discomfort while working; $81 \%$ suffer from constant stress which negatively influences their health and leads to cardiovascular diseases; $93 \%$ complain about the tiredness from nervous system overload; $68 \%$ claim not being able to cope with stress; $57 \%$ characterize the relations with school administration as incompatible. All of the mentioned above results in emotional breakdowns, neuroses, decrease of working efficiency, ormation of the cynical attitude to work and its objects (inhumane, emotionless attitude to pupils, etc.) [7, pp. 107-108].

In accordance with the results of the study by M. Zorina, $60 \%$ of teachers feel constant discomfort while working; $85 \%$ of them continually feel stress; $35 \%$ of female teachers have the illnesses of the nervous system as their profession negatively influences their family relations [9].

Having studied teachers' professional health considering the aspect of the duration of the pedagogical activity, E. Vasilevskaia has noticed that by the 25 years of work experience, one can notice not only the health deterioration but also a stop in the professional development, desire to use the set stereotypes, and overconfidence in professional impeccability. Furthermore, the researcher is sure that the discrepancies between the professional mobilization and energy resources cause professional misadaption [4].

Sadly, but according to the statistical data, owing to the impact of the negative professional factors, teachers in Ukraine occupy the first place in the list of top ten "conscious alcoholics" who are people that suffer from alcohol addiction but wants to recover [25].

What is paradoxical in this situation is that despite the general recognition of competency-based approach, the preparation of future teachers in the system of higher pedagogical education in Ukraine (as well as in other states) does not correspond to the challenges and tasks in the sphere of professional activity. Although, it is strange, for instance, to imagine an electrician who does not know about the influence of electricity in the organism, 
causes and types of electric injuries, first aid in a situation when one suffers from electrical shock, or an agriculturist who does not possess knowledge about the allowable levels of nitrates, safety measures while using chemical pesticides, their influence on the body, etc. Nevertheless, at the moment, the problem of the future teachers' preparation to the prevention of professional syndromes and illnesses is not highlighted deeply and in detail neither in the scientific nor in the civic circles.

At the same time, the preparation of the future teachers to the protection of their professional health is important not only from the point of view of pedagogics, psychology, methodology, medicine, sociology but also from the perspective of economy as in the countries where prevention rather than treatment is prioritized expenses of the government on the treatment decrease by $70 \%[20]$.

\section{The analysis if the latest studies and publications}

Despite the acuteness and significance of the problem under consideration, applied methods of its solution have not been sufficiently addressed although separate research results concerning the prevention of the professional illnesses among the students of the pedagogical specialities are of some value.

Thus, A. Osnitskii proposes to include the courses "Professional hygiene" and "Personal ecology in pedagogical activity" into the system of higher and post-graduate pedagogical education. In his opinion, in the future, it will give an opportunity to deal with professional maladjustment and increase the spare capacities of the organism [17].

E. Bagnetova has proved the efficiency of the formation of the future teachers' professional pedagogical culture (that, in the future, has to promote the professional health preservation) in the process of teaching special courses "The basis of the healthy way of living", "Healthcare science", "Hygiene of the physical education and sport", "Professional and pedagogical health culture of the students from the northern region" [2].

$\mathrm{N}$. Honcharova believes that the formation of the future teachers' health culture at the stage of professional preparation is an important approach to the solution of the problem. It can be realized through the creation of the united health saving educational space of higher educational establishment, inclusion of the issue into the content of the studied subjects, use of the therapeutic 
technologies at all stages of the development of the culture of professional health, formation and adoption of the system of health saving knowledge and skills (situations of simulation, self-regulation, and self-fulfillment). The researcher claims that as a consequence of such work, future educators will be able to develop the belief that the formulation of the personal program of the professional health preservation is really necessary [5].

Furthermore, N. Maliarchuk also emphasizes the necessity to instill the health culture in the future teachers and recommends preparing the educators to the personal health preservation through the development of the health saving motivation, health individualization and advance of the health culture. The researcher believes that it has to be accomplished through the introduction of courses such as "Rehabilitation pedagogics" and "Pedagogical valeology" [12].

P. Stankevych proposes to form the health preservation competency of the future teacher with the help of the series of general professional subjects [24].

V. Krasilov proves that the process of the professional preparation of the students of pedagogical specialties has to be based on the approach of health preservation. It will serve as a methodological principle and determine the content, organizational forms, methods and techniques of health preservation. This will help to reach the consistency of the process of professional preparation, develop important physical, mental, personal and professional qualities, use the enriching, educational and therapeutic possibilities of the physical education and sport to full advantage, and include all the subjects of the pedagogical process into the activity aimed at the health preservation and improvement [11].

Bakhtin, Solomin, Makarova and Syromiatnikova argue that the medical and valeological education of the teachers is a significant area of focus that promotes their health preservation. The necessary knowledge can be provided through the soecial courses such as "Developmental anatomy, physiology and hygiene", "The basis of the healthy way of life", "The basic knowledge about medicine and disease prevention", "The foundation of the social medicine", "The prevention of the social disorders (Preventology)" [3].

M. Pazyrkina, A. Soloviov, and H. Sopko focus their attention on the need to form the positive attitude to the personal health and develop the health culture. The mentioned above should be realized in the atmosphere of intellectual, moral and aesthetic excitement, clash of interests, opinions, 
search of truth, and development of various possible solutions. According to the researchers, the most suitable subjects for this are "Physical education", "Physiology", "Hygiene", "Anatomy", and "Psychology" [18;19].

I. Avdieienko is sure that the development of health culture is the main condition of the educators' successful future career. It has to be achieved through adding the information concerning health preservation to the educational program, inclusion of the additional tasks of the health saving orientation into the programs of teaching practice, development of the health culture in extra-curricular educational work [1].

H. Mieshko believes in the necessity of the course "Educator's professional health" in the system of higher pedagogical education. Its tasks include the acquisition of the knowledge about the professional health, formation of the value system and responsible attitude to health, familiarization with the main principles, forms and means of health saving activity, encouragement of students' aspiration for independent design of programs aimed at health preservation, motivation to search for the personal therapeutic systems, and formation of sanogenic (positive, health-improving) thinking [14].

$\mathrm{V}$. Elizarov is convinced in the efficiency of the formation of the students' valeological competency that, in his opinion, has to contribute to the decrease of the cases of professional illnesses through the means of extra-curricular educational work [8].

The analysis of the studies concerning the given issues makes it possible to claim that most researchers propose to solve the problem of the teachers' prevention of the professional illnesses by means of general valeologisation of the higher pedagogical education. In particular, one needs to form the value of health, motivate its preservation, lead healthy way of life, develop the health culture, etc.

All of the mentioned above is definitely right and, in our opinion, has to be present not only while preparing the future educator but also any other specialist. However, we are also sure that professional specific training has to be used alongside the general valeological one. It should consider the work factors that form the conditions of the professional activity as they serve as reasons of the appearance of the professional syndromes and illnesses and are common in the field of pedagogy in general and, at the same time, individual when one considers a particular educational establishment and a definite teacher. 
There are two main ways to solve the given problem that are proposed by the researchers: the introduction of one or few corresponding special courses and the improvement of the programs of academic disciplines against the background of the health-saving environment of an educational establishment.

No doubt, the introduction of one or a few of the special courses is the most optimal way. Nevertheless, the analysis of the data from various studies shows that in the conditions that can be observed in the Ukrainian education system now, it can be achieved only on the level of a separate university department or, more often, of a specific teacher within a framework of some definite research. That is why nowadays, the problem of the effective preparation of future teachers to the prevention of professional illnesses in the conditions of a short time span, that is within a framework of the improvement of programs of academic subjects, is really acute.

Speaking about the system of pedagogical education in Ukraine at present, we believe that the most suitable subject is "Occupational safety in the sphere" as the given subject is studied in the system of the higher pedagogical education with an aim to provide future professionals with the competence regarding health, life and work capacity preservation of the participants of the educational-bringing up process [26].

\section{Research results}

On the basis of the comparison of the data from the mentioned above scientific and methodological sources and experimental findings concerning the study of the unfavorable factors of general education environment, including the personal experience of teaching at school, that influence the educators' health [6], we have designed the technology of the formation of the future teachers' readiness to prevent professional syndromes and illnesses. The mentioned preparedness can be accomplished through the classroom and extracurricular activities and is based on the knowledge of physiological and psychological aspects of the mental labor, awareness of the negative factors of education environment and their influence on educators' health, understanding of the impact of the modern socio-cultural and economic factors on teachers' professional health, awareness of and understanding of the essence of professional illnesses, their first symptoms and dynamics. Moreover, the readiness can be achieved through the ability 
to diagnose professional health issues and design measures aimed at the prevention of the professional illnesses and syndromes.

The given technique has its peculiarities such as integrity (all conditions influencing the educator's professional health are considered), multidisciplinarity (knowledge of pedagogics, psychology, valeology, job safety, physiology and others are updated, deepened and formed), and creativity (the students' activity in the process of the preparation to the prevention of the professional syndromes and illnesses has mostly creative direction).

Contrary to similar studies, the distinguishing feature of the given research is its health and safety nature. Firstly, prevention of the professional syndromes and illnesses among educators is considered not only as a personal or humane aim or a part of the general pedagogical culture or health culture but also as the realization of the requirements of job safety. Secondly, the main condition of the prevention of professional syndromes and illnesses is knowledge, understanding and ability to make adjustments to the factors that form educator's working conditions.

We believe that knowledge, understanding and ability to make adjustments to the factors that form the educator's working conditions are not only the distinguishing but also conceptual peculiarity of the given technique. On one hand, they are the reason of the professional health disorders. On the other hand, they do not have stable character and implementing the analyzed technology on the basis of mere provision of students of pedagogical specialities with information about professional illnesses seems ineffective. For example, over the last years, there has been decline in the level of social respect to the profession of an educator. Moreover, due to the fast informatization, teachers have become active users of computer. Additionally, as T. Khagurov and A. Ostapenko state [27], because of the information overload, modern "informational" generation of pupils has turned into a real problem for the educational system like street children of the 1920s since their motivation and attention to studying have decreased. All of the mentioned factors have coincided with the waves of economic crises, worn-out state of the technological systems and highways, and also educational establishments, appearance of new technologies and materials that has fundamentally changed the factors that form the working conditions in a short period of time.

At the same time, according to our observations, the factors that have impact on the working conditions are dissimilar in different educational estab- 
lishments. For instance, if to consider a small village school, one can notice that the psychological environment there is much more favorable than in a big town school. The same is true for schools where the percentage of male teacher is higher. Furthermore, there are new-built educational establishments and those that are in critical condition. Additionally, the educator's professional health is influenced by his/her individual peculiarities: proneness to a specific illness (based on the heredity, previous diseases), type of thinking, temperament, number of experienced stresses, etc. That is why, the preparation to the prevention of the professional health disorders will be affective only if one considers all the mentioned above aspects.

The implementation of the devised technology has to start from a lecture that will focus on the physiological and psychological peculiarities of mental work and special features of the work activity in the system "individual-individual".

Next, students will proceed to study the generally accepted classification of factors that form the work conditions therefore influencing the professional health. Additionally, they will analyze them with regard to the educational environment.

In order to accomplish that, they will first get to know the existing norms and requirements of the working conditions, statutory documents with the summary of the demands, with their databases, and later, with the typical reasons of the negative influence of factors that shape the working conditions on the professional health (Table 1).

The data presented in Table 1 was received on the basis of the analysis of the results of the complex theoretical and practical study of negative factors of educational school environment [6].

After that, students learn the mechanisms of influence (usually, complex ones) of the unfavorable working conditions on the teachers' health. High neuropsychic tension is the reason of the fact that the teachers' state of social adequacy is close to the individuals suffering from neurosis. Chronic stress combined with excessive intellectual and informational tension lead to hypertension, ischemia, cardioneurosis, dystonia, psychasthenia, emotional burnout syndrome, stomach and stercoral ulcer, hypomotility of bile passages, psychogenic aphonia. Additionally, high biological load causes the illnesses of respiratory tract, and when combined with intensive voice strain, it provokes the appearance of laryngitis, tonsillitis, pharyngitis, 
The negative influence of factors that shape the working conditions on the educators' professional health

\begin{tabular}{|c|c|}
\hline $\begin{array}{l}\text { Factors } \\
\text { that shape } \\
\text { working } \\
\text { conditions }\end{array}$ & $\begin{array}{c}\text { Typical professional reasons of negative influence on the health } \\
\text { of the teachers of general educational institutions }\end{array}$ \\
\hline \multicolumn{2}{|r|}{ Sanitary and hygienic } \\
\hline Lighting & $\begin{array}{l}\text { Replacement of the older, traditional lights designed for } 100 \text { watt } \\
\text { lights bulbs by the modern ones } 60 \text { watt light bulbs; untimely } \\
\text { replacement of light bulbs when they burn out because of the } \\
\text { deterioration of their quality, poor financing of the educational } \\
\text { sphere; reduction of the window area when replacing old wooden } \\
\text { windows by the modern plastic ones. }\end{array}$ \\
\hline Temperature & $\begin{array}{l}\text { Lowered temperature because of the cost saving measures, untimely } \\
\text { beginning and ending of the heating season, irregular temperature } \\
\text { in educational facilities due to old heating systems and boiler } \\
\text { equipment, non-ergonomic main heat pipe. }\end{array}$ \\
\hline Ventilation & $\begin{array}{l}\text { Reduction of the ventilation panes area to save money while } \\
\text { replacing windows; mounting of cheap, non-certified windows with } \\
\text { poor mode of light ventilation; violation of the schedule of airing by } \\
\text { duty men and tech staff; excessive natural ventilation due to cracks } \\
\text { in windows; placement of doors proximal to prevailing winds; } \\
\text { untimely winterization of windows. }\end{array}$ \\
\hline Noise & $\begin{array}{l}\text { Surplus of the noise background due to irrational organization } \\
\text { of activity, low level of some pupils' discipline, overcrowding of } \\
\text { pupils owing to insufficient area of facilities and territory. }\end{array}$ \\
\hline $\begin{array}{l}\text { Harmful } \\
\text { substances, } \\
\text { dust }\end{array}$ & $\begin{array}{l}\text { Increase of the amount of chalk, dust, fibers of clothes because of } \\
\text { the violation of the schedule of wet cleaning and airing. }\end{array}$ \\
\hline $\begin{array}{l}\text { Biological } \\
\text { factors }\end{array}$ & $\begin{array}{l}\text { Susceptibility of the participants of the education process to } \\
\text { seasonal virus illnesses due to the lowered temperatures, violation } \\
\text { of sanitary and hygienic norms, increase of the amount of chalk, } \\
\text { dust, clothes fiber that irritate the mucous membranes of respiratory } \\
\text { tract and contribute to the penetration of the causative agents } \\
\text { of respiratory diseases, the presence of fungal spores due to the } \\
\text { appearance of mold because of the violation of the ventilation } \\
\text { schedule. }\end{array}$ \\
\hline
\end{tabular}


End of Table 1

\begin{tabular}{|c|c|}
\hline \multicolumn{2}{|r|}{ Psycho-physiological } \\
\hline $\begin{array}{l}\text { Neuro- } \\
\text { psychological } \\
\text { load }\end{array}$ & $\begin{array}{l}\text { Low level of social respect to the profession of a teacher; absence } \\
\text { of balance between the efforts made and salary; cost cutting when } \\
\text { dealing with business trip permits; toughening of requirements } \\
\text { regarding the advancements of the teaching category; continuous } \\
\text { changes of curriculum, textbooks; high responsibility for educational } \\
\text { activity of pupils; preservation of pupils' health and life; provision of } \\
\text { discipline during breaks; preservation of property of the educational } \\
\text { establishment; redecoration on classrooms; high nervous, intellectual, } \\
\text { noise, visual and informational tension; fulfillment of supervising not } \\
\text { advisory functions; compulsory participation in contests like "Teacher } \\
\text { of the year", "Class teacher of the year", fairs of professional mastery, } \\
\text { population census, amateur performances, meeting with deputies, etc.; } \\
\text { fulfillment of mentor's functions in school camps in the conditions } \\
\text { of the absence of the relevant material and technical base; excessive } \\
\text { bureaucratization and formalization of the educational process; high } \\
\text { number of pupils in classes. }\end{array}$ \\
\hline $\begin{array}{l}\text { Working } \\
\text { posture }\end{array}$ & $\begin{array}{l}\text { Stagnant processes in lower limbs, pelvic organs and spine due to long } \\
\text { period of standing or sitting; tension of the eyes and vocal apparatus. }\end{array}$ \\
\hline $\begin{array}{l}\text { Modes of work } \\
\text { and rest }\end{array}$ & $\begin{array}{l}\text { The actual excess of the specified working time in } 2-3 \text { times; uneven } \\
\text { workload; the scheduling of lessons and duties at school in violation } \\
\text { of applicable requirements; intensification of activities after the } \\
\text { quarantine. }\end{array}$ \\
\hline Risk of injury & $\begin{array}{l}\text { A large number of psychological traumas due to the administrative- } \\
\text { totalitarian style of governance in the educational system, increasing } \\
\text { demands for teachers, high levels of neuropsychic tension. }\end{array}$ \\
\hline \multicolumn{2}{|r|}{$\begin{array}{c}\text { Aesthetic } \\
\end{array}$} \\
\hline $\begin{array}{l}\text { Light and color } \\
\text { composition }\end{array}$ & $\begin{array}{l}\text { Violation of norms of color scheme of facilities in general and } \\
\text { depending on where the classroom windows overlook. }\end{array}$ \\
\hline \begin{tabular}{l|} 
Art and \\
constructive \\
design of the \\
working zone
\end{tabular} & $\begin{array}{l}\text { Very close placement of teacher's desk to the blackboard and } \\
\text { students' desks; use of old furniture; absence of places for } \\
\text { psychological relaxation during breaks or free time between classes. }\end{array}$ \\
\hline \multicolumn{2}{|r|}{ Socio-psychological } \\
\hline $\begin{array}{l}\text { Psychological } \\
\text { microclimate, } \\
\text { nature of group } \\
\text { and intergroup } \\
\text { relations }\end{array}$ & $\begin{array}{l}\text { Typically female staff of general educational establishments; } \\
\text { different treatment of teachers by school administration depending } \\
\text { on personal preferences and relations that is reflected while creating } \\
\text { timetable, deciding on the workload, etc.; conflicts between teachers } \\
\text { of different subjects who try to prove that their discipline is more } \\
\text { important; conflicts between the teachers of different generations on } \\
\text { ground of methodological and educational approaches. }\end{array}$ \\
\hline
\end{tabular}


aphonia. Furthermore, constant eyestrain and violation of lighting norms in classrooms are the reasons of the dry eye syndrome, painful eye watering, effusion of blood into eyes, loss of visual acuity, nearsightedness, far-sightedness, and astigmatism. Finally, insufficient physical activity lead to hypodynamia, and together with the working postures, provokes varicose veins, osteochondrosis and visceroptosis among thin individuals.

In addition, students get to know the age, gender and qualification peculiarities of the proneness to professional illnesses [22].

Later, the discussion of the issue under consideration takes place on the tutorials such as "Stress as a negative factor of the school educational environment" and "Teachers' professional syndromes and illnesses".

The tutorial "Stress as a negative factor of the school educational environment" is bidirectional. In particular, it is devoted to the reasons, prevention and management of school stress of both pupils and teachers. Let us focus on those aspects of the tutorial that are connected with the professional health issues of the latter.

With regard to theoretical information, students actualize the received earlier knowledge about phases of stress, its physical and psychological symptoms and learn modern educational and socio-economic reasons of its appearance among the subjects of educational process at school. Moreover, they consider the two-way relationship between stress experienced by teachers and the one felt by pupils, analyze the influence of the type of thinking (sanogenic or pathogenic) on the levels of stress tension and impact of stress on the professional illnesses.

For the individual work, students receive task to use their experience of studying at school and having internship there in order to provide examples of the serious stress felt by teachers and develop general recommendations to relieve the tension.

On the tutorial, students take two tests: one of them helps to determine the personal stress-resistance level while the other one gives an opportunity to designate the consequences of stressful situations experienced during the previous calendar year using the H. Anderson's stress scale.

After that, on the basis of the test results (as stress is the main cause or catalyst of the illnesses), analysis of the individual peculiarities of the own organism, the future educators make inferences about the personal proneness to professional diseases. 
The next step is the exchange of the personal experience of relieving stress.

To continue, in the theoretical part of the tutorial "Teachers' professional syndromes and illnesses", students continue learning about the peculiarities of the influence of mental labor on the organism and modern tendencies present in the society and educational system that negatively influence educators' health.

The following tasks are provided for the individual work:

1. To analyze professional syndromes and illnesses according to the scheme "professional syndrome or illness, signs and symptoms, causes, preventive measures".

2. To explain the influence of individual gender and age peculiarities on the proneness to professional illnesses.

3. To develop general recommendations for the teachers concerning the prevention of professional syndromes and illnesses.

The fulfillment of the mentioned tasks requires students' intellectual, cognitive, information-retrieval, scientific, analytical, synthetic and project activity and foresees the work with academic and scientific research literature.

The tutorial is conducted according to the presented above plan.

\section{Plan}

1. Influence of social environment on the teachers' professional illness frequency.

2. Educational reasons of teachers' professional syndromes and illnesses.

3. Teachers' professional syndromes and illnesses: types, signs and syndromes, causes and preventive measures.

4. Peculiarities leading to the proneness to professional illnesses.

5. General technologies of prevention of professional illnesses and syndromes.

Besides, the topic of professional illnesses is included into the modular tests and list of questions to be prepared for exam.

The first experience of using the given technology has proved its efficiency. One could notice elevated emotional background among the students of different specialities. They strove to discuss their test results, found the signs of stress and proneness to professional syndromes not only in themselves but also in their relatives especially those working in educational establishments. Based on their own life experience and pedagogical internship, they agreed that there is close relation between the number of 
overcome stressful situations and health state (including the professional one). This fact led to high level of motivation to get prepared to the prevention of professional illnesses.

While planning the discussed above tutorial, we realized that the topic is rather multidiscipline and knew that students would have corresponding questions based on personal treatment of the problem of professional illnesses in particular and suffering from diseases in general. That is why we had worked with a big amount of pedagogical, psychological, labor safety, physiological and medical literature. We had also consulted practicing doctors. This gave the opportunity to present competently not only theoretical but also practical part of the studied topic during the tutorial and outside it.

Let us pay attention to the most prominent cases of students' asking questions that have proved the significance and relevance of the topic while approbation of the designed technology.

Case 1. The students of the specialization "Physical education and sport", weightlifter asked for permission to demonstrate his shin in order to check if he does not have varicose veins. He was told that it is a doctor who should make a diagnosis; however, according to the signs, he actually had varicose veins and was advised to consult a vascular surgeon. Moreover, in all likelihood, the illness was caused by weightlifting activity.

The student's visit to the doctor proved the hypothesis, and he informed us about that on the next tutorial which led to a new wave of other learners' keen interest to that fact of how different kinds of sport influence the body. Besides, they wanted to find out if the sport diet is harmful or not.

Case 2. A student of the fifth year told that she had been having sleeping problems for 2 weeks. She had consulted a general practitioner, undergone some tests, however, no problem had been identified. For some reason, the general practitioner had not told her to visit other specialists. Answering the question if she had been experiencing serious stress recently, she told that for months before, her boyfriend had died. We advised her to consult a psychotherapist who made a conclusion that her condition was a consequence of the experienced stress.

Case 3. 34-year-old extra-mural student was taking her exams a month and a half later due to her health state. She asked if the factors of professional activity could be the reason of a cough that she had been having for 2 months, and which had caused hoarseness and dysphonia. At the same 
time, she told that doctors prescribed her powerful antiviral drugs, antibiotics and even antituberculotics but nothing had helped her. First, we had suspicions that she worked in some industrial enterprise or lived near one, and we asked her about her workplace and place of residence. The student answered that she worked as a tutor in a dorm of vocational school where she actually lived. Then, we had the following dialogue:

- Is there mold in the dormitory?

- There is one is the dorm but not in my room as I have got rid of it using special products and have made renovations.

- Do you know that mold spores are very light and can be transmitted to great distances? If there is mold in the dormitory, its spores are present in your room.

- What should I do?

- You need to undergo allergy testing as you might have an allergy to mold or product you used to fight it.

As we learned later, the student was suffering from an allergy to mold. When she moved, all the symptoms disappeared.

Case 4. A postgraduate student, who worked as a teacher of Ukrainian philology, told that from time to time, she experienced palpitation. She had consulted a cardiologist and had been carefully examined. However, no problems had been identified. The doctor even joked, "You can become an astronaut with such a good cardiogram and test results".

Our advice was to pay attention to the description of cardiac neurosis while preparing for the tutorial and try to recall if any recurrent stressful situation coincided with palpitation issues.

On the following tutorial, the student told that having considered all the facts and events, she discovered that her issues started before the visit of a representative of a methodological union, school administration or department of education to her lesson. The primary reason was the fact that she suffered from severe stress when she got many remarks concerning her first demo lesson. At the moment of the tutorial, her school was to undergo the audit, thus, her heartbeat became higher.

The described above cases are not occasional. Students ask a lot of similar questions especially extra-mural and postgraduate ones as those groups include higher number of older students and those who work at school. Some of them hear questions or stories about the further development of 
events and notice that they or their colleagues have similar symptoms and illnesses. Moreover, some of them find the source of their health problems or determine the factors (professional, individual or complex) that lead to the issues while preparing to the tutorials or actually at the tutorial itself.

To approbate the given technology on the quantitative level, there were two groups formed: the control group (CG) where the approach was not used and the experimental group (EG) where the technique was applied. Moreover, a special questionnaire presented below was created. It is necessary to note that in order to reduce errors, the groups were formed from students of the same pedagogical specialities in equal numbers, namely 60 people in each of them.

\section{QUESTIONNAIRE}

\section{Dear students, we ask you to answer the given below questions.} This questionnaire is conducted with the aim to improve the professional preparation of the future teachers. You answers will be used only with scientific purpose.

1.Name the physiological peculiarities of the mental labor.

2. Name the psychological peculiarities of the mental labor.

3. Name the main factors of the modern system of education that negatively influence the professional health and longevity of teachers.

4. Name educators' professional illnesses and syndromes.

5.Describe the symptoms of professional illnesses and syndromes of teachers.

6. Name the methods of prevention of the stated illnesses and syndromes.

7. Explain how the individual peculiarities influence the proneness to professional syndromes and illnesses.

8. Explain how the gender peculiarities affect the susceptibility to professional illnesses and syndromes.

9. Explain how the age peculiarities influence the proneness to the professional syndromes and illnesses.

10. Can you predict how the hereditary (if present) and experienced by you illnesses will influence the susceptibility to professional health disorders.

\section{Thank you for taking part in the questionnaire!}

Having analyzed the results of the given questionnaire it turned out that only $78 \%$ of EG and $7 \%$ of CG were able to name the physiological pecu- 
liarities of mental labor, and $88 \%$ of EG and $32 \%$ of the CG listed the psychological ones. $92 \%$ of the members of EG and $43 \%$ of the CG specified the main factors of the modern educational system that negatively influence the health and longevity of teachers. $95 \%$ of the EG and $3 \%$ of the CG were able to list all the professional illnesses and syndromes while $88 \%$ of the EG and $5 \%$ of the CG managed to describe their symptoms. $85 \%$ of the EG and $3 \%$ of the $\mathrm{CG}$ named the methods of prevention of all the professional syndromes and illnesses, and $87 \%$ of the EG and $18 \%$ of the CG explained how the individual peculiarities influence the susceptibility to the professional syndromes and illnesses. The effect of the gender peculiarities on the proneness to the professional syndromes and illnesses was specified by $70 \%$ of the EG and $8 \%$ of the CG while the impact of gender peculiarities was described by $93 \%$ of the EG and $20 \%$ of the CG. Lastly, $93 \%$ of the EG and $7 \%$ of the $C G$ predicted how the hereditary (if present) and experienced illnesses could influence the susceptibility to professional health disorders.

The general level of knowledge about the professional syndromes and illnesses determined through the arithmetic mean method equals to $87 \%$ in the EG and $15 \%$ in the CG. The difference in the figures is $72 \%$ in favor of the experimental group.

Therefore, the designed by us system of the formation of future teachers' readiness to the prevention of professional syndromes and illnesses proved its efficiency.

\section{Conclusions}

The critical state of teachers' health is an important problem of the modern educational environment is pedagogical, humane, medical and social aspects. On the background of other unfavorable conditions, it negatively influenced the health of the next generation and effectiveness of the educational process.

One of the main reasons of such a situation is insufficient preparation of students of pedagogical specialization in the system of higher pedagogical education to the prevention of professional syndromes and illnesses.

Therefore, we have developed a technology of the future teachers' preparation to the prevention of the professional syndromes and illnesses that is accomplished through classroom and extracurricular activities. The approach is based on the knowledge of physiological and psychological 
aspects of mental labor; awareness of the negative factors of the general educational environment and their influence on teachers' health; understanding of the effect of modern socio-cultural and economic factors on educators' professional health; knowledge and understanding of the essence of teachers' professional illnesses, their preliminary symptoms and mechanisms of manifestation; ability to diagnose the professional health disorders; ability to organize precautionary actions to prevent the appearance of professional illnesses and syndromes.

The distinguishing feature of the given scheme is its health and safety character as contrary to the similar ones. Firstly, it views the prevention of teachers' professional syndromes and illnesses not only as a personal or humane aim or a part of the general educational culture, but also as realization of the safety requirements. Secondly, knowledge, understanding and ability to correct factors that form teachers' working environment are the fundamental condition of the prevention of professional syndromes and illnesses.

The peculiarities of the given approach are complexity, multidisciplinarity and creativity.

In case of absence of the course "Labor safety in the field", the developed technology or its elements can be used in other academic courses or in the system of teachers' post-graduate education.

\section{References:}

1. Avdjejenko I.A. (2016). Rozvytok kuljtury zdorov'ja studentiv v osvitnjomu seredovyshhi vyshhogho navchaljnogho zakladu [Development of students' health culture in the educational environment at an institution of higher education] (avtoref. dys. ... kand. ped. n.: 13.00.07). Kharkiv.

2. Bagnetova E.A. (2004). Formirovanie professional'no-pedagogicheskoj kul 'tury zdorov'a studentov pedagogicheskogo vuza [Formation of the professional and pedagogical healf culture of the students of the pedagogical higher educational establishment] (avtoref. dys. ... kand. ped. nauk: 13.00.08). Surgut.

3. Bahtin Ju.K., Solomin V.P., Makarova L.P., Syromjatnikova L.I. (2012). Znachenie mediko-valeologicheskogo obrazovanija studentov i opyt ego realizacii $\mathrm{v}$ pedagogicheskom universitete [The significance of the students' medical valeological education and experience of its implementation in the pedagogical university]. Molodoj uchenyj, 6, 372-375.

4. Vasilevskaja E.A. (2011). Professional'noe zdorov'e pedagoga kak faktor sovershenstvovanija zdorov'esberegajushhej obrazovatel'noj sredy [The educator's professional health as a factor of the improvement of the health saving educational environment]. Vektor nauki Tol'jattinskogo gosudarstvennogo universiteta, 1(15), 375-378. 
5. Goncharova N.V. (2005). Formirovanie kul'tury professional'nogo zdorov'ja budushhego uchitelja [The formation of the future teacher's culture of theprofessional health] (avtoref. dys. ... kand. ped. n.: 13.00.08). Volgograd.

6. Ghlinchuk Yu. (2014). Neghatyvni vyrobnychi chynnyky suchasnogho zaghaljnoosvitnjogho shkiljnogho seredovyshha [The negative production factors of the modern comprehensive school environment]. Nova pedaghoghichna dumka, 4(80), 92-95.

7. Dolynsjkyj B.T. (2011). Teoretyko-metodychni zasady pidghotovky majbutnikh uchyteliv do formuvannja zdorov'jazberezhuvaljnykh navychok $i$ vminj $u$ molodshykh shkoljariv u navchaljno-vykhovnij dijaljnosti [Theoreticalmethodical bases of future teachers' preparation to the formation of health saving skills in primary school pupils in the educational/bringing up activity] (dys.... dokt. ped. nauk: 13.00.04). Odesa.

8. Jelizarov V.P. (2016). Formuvannja valeologhichnoji kompetentnosti studentiv $u$ pozaaudytorij vykhovnij roboti universytetu [The formation of students'valeological competence in extracurricular educational work of the university] (avtoref. dys. ... dokt. ped. n.: 13.00.02). Kharkiv.

9. Zorina M.O. (2013). Profesijne zdorov'ja vchytelja jak vazhlyva skladova jogho dijaljnosti [The teacher's professional health as an important part of his/ her activity]. Pedaghoghika formuvannja tvorchoji osobystosti u vyshhij $i$ zaghaljnoosvitnij shkolakh, 33(86), 175-179.

10. Kolomijceva O.E. (2006). Optymizacija profesijno-prykladnoji fizychnoji pidghotovky studentiv serednikh ghumanitarnykh navchaljnykh zakladiv [The optimization of the professional-applied physical education in students of the humanitarian secondary educational establishments] (avtoref. dys. ... kand. nauk z fiz. vykh. ta sportu: 24.00.02). Kharkiv.

11. Krasilov V.M. (2009). Zdorov'esberegajushhij podhod $k$ organizacii vospitatel'no-obrazovatel'nogo processa v uchrezhdenii nachal'nogo professional'nogo obrazovanija [The health-saving approach to the organization of the educational/bringing up process in the establishment of the primary vocational education]. (avtoref. dys. ... kand. ped. nauk: 13.00.08). Novokuzneck.

12. Maljarchuk N.N. (2008). Formirovanie kul'tury zdorov'ja pedagogov [The formation of the educators' health culture]. Vestnik Tjumenskogo gosudarstvennogo universiteta, $5,108-117$.

13. Meshko H.M. (2005). Profesijne zdorov'ja pedaghogha jak umova efektyvnoji vykhovnoji dijaljnosti [The educator's professional health as a condition of the effective educational activity]. Visnyk Zhytomyrsjkogho derzhavnogho universytetu imeni Ivana Franka, 24, 94-96.

14. Meshko H.M. (2008). Formuvannja strateghiji zberezhennja profesijnogho zdorov'ja pedaghoghiv na etapi fakhovoji pidghotovky [The development of the strategy aimed at saving educator's health on the stage of the professional training]. Visnyk Cherkasjkogho universytetu, 136, 133-136.

15. Mokaeva M. (2010). Psihologicheskoe zdorov'e pedagoga kak uslovie ego jeffektivnoj dejatel'nosti [Teacher's psychological health as a condition of his/her effective activity]. Pedagogicheskoe obrazovanie Rossii, 3, 37-41. 
16. Nikiforov G.S. (2002). Psihologiya zdorovya: ucheb. posobie [Health Psychology: Study Guide]. Sankt-Peterburg: Rech, 256 p.

17. Osnickij A.V. (2003). Problemy psihicheskogo zdorov'ja $i$ adaptacii lichnosti [The problems of psychological health and personal adaptation]. SanktPeterburg: Serebrjannyj vek, $379 \mathrm{p}$.

18. Pazyrkina M.V., Solov'jov A.V. (2014). Formirovanie kompetencii zdorov'esberezhenija budushhih pedagogov [The formation of the future teachers' health saving competency]. Molodoj uchenyj, 2(61), 818-820.

19. Pazyrkina M.V., Sopko G.I. (2013). Znachenie formirovanija zdorov'esberegajushhih kompetencij pedagoga [The significance of the teacher's health saving competency]. Shkola budushhego, 2, 138-142.

20. Platonov V.N. (2006). Sohranenie i ukreplenie zdorov'ja ljudej - prioritetnoe napravlenie sovremennogo zdravohranenija [Preservation and strengthening of people's health as a priority of modern healthcare]. Sportivnaja medicina, 2, 3-14.

21. Practirum po psihologii zdorov'ja [The tutorial redarging health psihology] (2005). red. Nikiforov, G.S. Sankt-Peterburg: Piter, 351 p.

22. Profesijni zakhvorjuvannja ta jikhnja profilaktyka [Professional illnesses and their prevention] (2011): red. Flombojm, A.V. Kyjiv: Shkiljnyj svit, 104 p.

23. TOP-10 pytushhykh profesij [Top 10 drinking jobs] (2010). Dyrektor shkoly Ukrajiny, 5, 62 .

24. Typova navchaljna proghrama normatyvnoji dyscypliny "Okhorona praci $v$ ghaluzi» (2011). Kyiv, 15 p.

25. Slovnyk psykhologho-pedaghoghichnykh terminiv [The glossary of psychological and pedagogical notions]. URL: http://osvita.ua/school/method/ psychology/1270/ (accessed: 17.02.2017).

26. Stankevich P.V. (2009). Obnovlenie sistemy estestvennonauchnogo pedagogicheskogo obrazovanija kak rezul'tat standartizacii vysshego professional'nogo obrazovanija [The renewal of the system of natural science pedagogical education as a result of the standardization of the higher professional education]. Nauka i shkola, 1, 3-5.

27. Hagurov T.A., Ostapenko A.A. (2014). Reforma obrazovanija glazami uchitelej i prepodavatelej [The educational reform as viewed by teachers and educators]. Sociologicheskie issledovanija, 1, 103-107. 